\title{
Front Matter: Volume 7322
}

, "Front Matter: Volume 7322," Proc. SPIE 7322, Photonic Microdevices/ Microstructures for Sensing, 732201 (22 May 2009); doi: 10.1117/12.833494

SPIE Event: SPIE Defense, Security, and Sensing, 2009, Orlando, Florida, United SPIE. States 


\section{PROCEEDINGS OF SPIE}

\section{Photonic Microdevices/Microstructures for Sensing}

Hai Xiao

Xudong Fan

Anbo Wang

Editors

16-17 April 2009

Orlando, Florida, United States

Volume 7322

Proceedings of SPIE, 0277-786X, v. 7322 
The papers included in this volume were part of the technical conference cited on the cover and title page. Papers were selected and subject to review by the editors and conference program committee. Some conference presentations may not be available for publication. The papers published in these proceedings reflect the work and thoughts of the authors and are published herein as submitted. The publisher is not responsible for the validity of the information or for any outcomes resulting from reliance thereon.

Please use the following format to cite material from this book:

Author(s), "Title of Paper," in Photonic Microdevices/Microstructures for Sensing, edited by Hai Xiao, Xudong Fan, Anbo Wang, Proceedings of SPIE Vol. 7322 (SPIE, Bellingham, WA, 2009) Article CID Number.

ISSN 0277-786X

ISBN 9780819475886

Published by

SPIE

P.O. Box 10, Bellingham, Washington 98227-0010 USA

Telephone +1 3606763290 (Pacific Time) · Fax +1 3606471445

SPIE.org

Copyright (C) 2009, Society of Photo-Optical Instrumentation Engineers

Copying of material in this book for internal or personal use, or for the internal or personal use of specific clients, beyond the fair use provisions granted by the U.S. Copyright Law is authorized by SPIE subject to payment of copying fees. The Transactional Reporting Service base fee for this volume is $\$ 18.00$ per article (or portion thereof), which should be paid directly to the Copyright Clearance Center (CCC), 222 Rosewood Drive, Danvers, MA 01923. Payment may also be made electronically through CCC Online at copyright.com. Other copying for republication, resale, advertising or promotion, or any form of systematic or multiple reproduction of any material in this book is prohibited except with permission in writing from the publisher. The CCC fee code is 0277-786X/09/\$18.00.

Printed in the United States of America.

Publication of record for individual papers is online in the SPIE Digital Library.

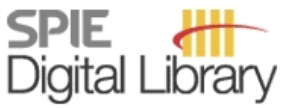

SPIEDigitalLibrary.org

Paper Numbering: Proceedings of SPIE follow an e-First publication model, with papers published first online and then in print and on CD-ROM. Papers are published as they are submitted and meet publication criteria. A unique, consistent, permanent citation identifier (CID) number is assigned to each article at the time of the first publication. Utilization of CIDs allows articles to be fully citable as soon they are published online, and connects the same identifier to all online, print, and electronic versions of the publication. SPIE uses a six-digit CID article numbering system in which:

- The first four digits correspond to the SPIE volume number.

- The last two digits indicate publication order within the volume using a Base 36 numbering system employing both numerals and letters. These two-number sets start with 00, 01, 02, 03, 04, $05,06,07,08,09,0 A, 0 B \ldots 0 Z$, followed by 10-1Z, 20-2Z, etc.

The CID number appears on each page of the manuscript. The complete citation is used on the first page, and an abbreviated version on subsequent pages. Numbers in the index correspond to the last two digits of the six-digit CID number. 


\section{Contents}

$\checkmark$ Conference Committee

\section{SESSION 1 MICROPHOTONIC DEVICES FOR BIOSENSING I}

732203 Fiber inline core-cladding-mode interferometer fabricated by $\mathrm{CO}_{2}$ laser irradiation [7322-16]

T. Wei, X. Lan, Y. Zhang, H. Xiao, Missouri Univ. of Science and Technology (United States)

732204 Optofluidic ring resonator sensor for sensitive label-free detection of breast cancer antigen CA15-3 in human serum [7322-03]

H. Zhu, Univ. of Missouri, Columbia (United States); P. S. Dale, Ellis Fischel Cancer Ctr. (United States); X. Fan, Univ. of Missouri, Columbia (United States)

732205 Porous waveguide in the Kretschmann configuration for small molecule detection [7322-04] Y. Jiao, G. Rong, S. M. Weiss, Vanderbilt Univ. (United States)

732206 Microfluidic and nanofluidic integration of plasmonic substrates for biosensing (Invited Paper) [7322-05]

D. Sinton, P. Wood, C. Escobedo, F. Eftekhari, J. Ferreira, A. G. Brolo, R. Gordon, Univ. of Victoria (Canada)

732208 Label-free DNA methylation analysis using the optofluidic ring resonator sensor [7322-07] J. D. Suter, D. J. Howard, C. W. Caldwell, Univ. of Missouri, Columbia (United States); H. Shi, Univ. of Missouri, Columbia (United States) and Medical College of Georgia Cancer Ctr. (United States); X. Fan, Univ. of Missouri, Columbia (United States)

\section{SESSION 2 MICROPHOTONIC DEVICES FOR BIOSENSING II}

7322 OA Waveguide evanescent field fluorescence microscopy: from cell-substratum distances to kinetic cell behaviour (Invited Paper) [7322-09]

A. Hassanzadeh, H. K. Ma, The Univ. of Western Ontario (Canada); S. Armstrong, S. J. Dixon, S. M. Sims, Schulich School of Medicine and Dentistry, The Univ. of Western Ontario (Canada); S. Mittler, The Univ. Of Western Ontario (Canada)

7322 OB Photonic crystal slab and waveguide design for biological detection [7322-10] E. Tanner, J. Arch, A.-M. Dorsett, Kratos Defense and Security Solutions (United States); D. Strembicke, M. Buncick, AEgis Technologies Group, Inc. (United States); J. Han, HudsonAlpha Institute for Biotechnology (United States); S. Retterer, D. Thomas, Ctr. for Nanophase Materials Sciences, Oak Ridge National Lab. (United States) 
7322 OC Nanocrystalline Cu-doped zirconia film-coated long-period fiber grating for CO monitoring at high temperature (Invited Paper) [7322-11]

X. Tang, J. Zhang, J. Dong, Univ. of Cincinnati (United States); T. Wei, H. Xiao, Missouri Univ. of Science and Technology (United States)

7322 OD Detection of CD4+ and CD8 + T-lymphocytes with the optofluidic ring resonator (OFRR) biosensor [7322-19]

J. T. Gohring, X. Fan, Univ. of Missouri, Columbia (United States)

7322 OE Development of optofluidic ring resonator based chemical vapor sensing platform [7322-13]

Y. Sun, J. Liu, Univ. of Missouri, Columbia (United States); G. Frye-Mason, A. Thompson, S. Ja, ICX Technologies, Inc. (United States); X. Fan, Univ. of Missouri, Columbia (United States)

7322 OF Miniaturized fiber inline Fabry-Pérot interferometer for chemical sensing [7322-14]

T. Wei, Y. Han, H.-L. Tsai, H. Xiao, Missouri Univ. of Science and Technology (United States)

\section{SESSION 4 ROBUST MICROPHOTONIC SENSORS AND APPLICATIONS IN EXTREME ENVIRONMENTS}

7322 0J Study on $\mathrm{CO}_{2}$ laser irradiation-induced mode coupling for development of miniaturized interferometric sensors [7322-20]

X. Lan, T. Wei, Missouri Univ. of Science and Technology (United States); X. Tang, Univ. of Cincinnati (United States); Y. Zhang, Missouri Univ. of Science and Technology (United States); J. Dong, Univ. of Cincinnati (United States); H. Xiao, Missouri Univ. of Science and Technology (United States)

\section{SESSION 5 MICROPHOTONIC SENSOR FABRICATION}

7322 OK Fiber optics low-coherence IR interferometry for defense sensors manufacturing [7322-21] W. J. Walecki, F. Szondy, Sunrise Optical LLC (United States)

7322 OL All optically-driven MEMS deformable device via an array of photodetectors [7322-22] B. Haji-saeed, J. Khoury, K. Vaccaro, C. L. Woods, Air Force Research Lab. (United States); J. Kierstead, B. Krejca, A. Davis, Solid State Scientific Corp. (United States); W. D. Goodhue, Univ. of Massachusetts, Lowell (United States)

$73220 \mathrm{M}$ Theoretical and experimental development of label-free biosensors based on localized plasmon resonances on nanohole and nanopillar arrays [7322-02] R. A. Potyrailo, K. Dovidenko, L. A. Le Tarte, C. Surman, A. Pris, GE Global Research (United States)

$73220 N \quad$ Photonic bandgap fiber-enabled Raman detection of nitrogen gas [7322-12]

R. Chen, P. J. Codella, R. Guida, A. Zribi, A. Vert, R. Potyrailo, GE Global Research (United States); M. Baller, GE Global Research (Germany) 


\section{Conference Committee}

Symposium Chair

Ray O. Johnson, Lockheed Martin Corporation (United States)

Symposium Cochair

Michael T. Eismann, Air Force Research Laboratory (United States)

Conference Chairs

Hai Xiao, Missouri University of Science and Technology (United States)

Xudong Fan, University of Missouri, Columbia (United States)

Anbo Wang, Virginia Polytechnic Institute and State University (United States)

Program Committee

Brian T. Cunningham, University of Illinois at Urbana-Champaign (United States)

Junhang Dong, University of Cincinnati (United States)

Wei Jin, The Hong Kong Polytechnic University (Hong Kong China)

Susan M. Maley, U.S. Dept. of Energy, National Energy Technology Laboratory (United States)

Radislav A. Potyrailo, GE Global Research (United States)

Yun-Jiang Rao, University of Electronic Science and Technology of China (China)

Sharon M. Weiss, Vanderbilt University (United States)

Ian M. White, University of Maryland, College Park (United States)

John X. J. Zhang, The University of Texas at Austin (United States)

Yibing Zhang, ExxonMobil Research and Engineering Company (United States)

Mohammed M. Zourob, Biophage Pharma Inc. (Canada)

Session Chairs

1 Microphotonic Devices for Biosensing I

Ian M. White, University of Maryland, College Park (United States)

2 Microphotonic Devices for Biosensing II

Sharon M. Weiss, Vanderbilt University (United States)

3 Microphotonic Sensors for Chemical Detection

Xudong Fan, University of Missouri, Columbia (United States) 
4 Robust Microphotonic Sensors and Applications in Extreme Environments

Junhang Dong, University of Cincinnati (United States)

5 Microphotonic Sensor Fabrication

Hai Xiao, Missouri University of Science and Technology (United States) 